\title{
NOTE
}

\section{Fission track ages of the Omine Acidic Rocks, Kii Peninsula, Southwest Japan}

\author{
Noriko Hasebe, ${ }^{1}$ BAmbang Widoyoko SuWARgadi ${ }^{2}$ and Susumu Nishimura ${ }^{3}$ \\ ${ }^{1}$ Department of Earth Sciences, Faculty of Science, Kanazawa University, Kanazawa 920-1192, Japan \\ ${ }^{2}$ Puslitbang Geoteknologi, LIPI., Cisitu Baru, Bandong, Indonesia \\ ${ }^{3}$ Kyoto Institute of Natural History, Kinki-chiho Hatsumei Center, Kyoto 606-8305, Japan
}

(Received April 14, 1999; Accepted November 23, 1999)

\begin{abstract}
Fission track (FT) ages of the Omine Acidic Rocks, one of the Tertiary granitic rocks which occurs in the Outer Zone of the Median Tectonic Line, Southwest Japan, are determined in order to assess the timing of intrusion. Nine FT zircon (ZR) ages and one apatite (AP) age are obtained for igneous rocks, and four $\mathrm{ZR}$ ages for basement sandstone. Data for each pluton are concordant within a body representing the time of intrusion. The ZR ages from sandstone are concordant with the nearest pluton. The ages of plutons are classified into two groups statistically, suggesting that the Omine Acidic Rocks formed by two intrusive events. The Dorogawa, Tenguyama, Shiratani and Katago-Mukuro Dike are the older group with the weighted mean age of $16.8 \pm 0.8 \mathrm{Ma}$, and the Kose pluton are the younger with an age of 14.2 $\pm 1.7 \mathrm{Ma}$.
\end{abstract}

\section{INTRODUCTION}

More than fifteen Tertiary intrusive granitic rocks are known as the "Outer Zone Granite" in the Shimanto Belt, Outer Zone of the Median Tectonic Line in Southwest Japan. These igneous activities were considered to be contemporaneous at around $14 \mathrm{Ma}$ (Shibata, 1978; Shibata and Nozawa, 1967), and were attributed to a tectonic event which widely affected the thermal regime of the forearc area of $\sim 1200 \mathrm{~km}$ long, from the Kii peninsula to Kyushu. Considering their timing, it was deduced that the tectonic framework of southwest Japan region at Miocene, remarked by the opening of the Shikoku Basin plate (Chamot-Rooke et al., 1987) and the clockwise rotation of the Southwest Japan block (Otofuji et al., 1985), might be responsible for these igneous events.

A precise determination of the age-space distribution of granites is a fundamental need to understand the relationship between the granitic magma intrusion and tectonic framework at the time. Because of their possible complicated histories, the emplacement ages of granites should be estimated after investigation of their cooling histories by means of an age mapping and a combination of several dating techniques. At the beginning of studies on ages of the Outer Zone Granites, however, an age of each granite was estimated using data from one locality without investigation of its cooling history (Shibata and Nozawa, 1967). Recent researches (e.g., Murakami et al., 1989; Iwaya and Mimura, 1992; Dai et al., 1993; Hasebe et al., 1993; Tagami and Shimada, 1996; Sumii et al., 1998) re-estimate their emplacement ages carefully, still supporting the contemporaneity of the Outer Zone Granite intrusion.

In this study the fission-track (FT) ages were determined on zircon and apatite crystals to assess the time of intrusion of the Omine Acidic Rocks (OARs). The OARs are one of the Outer Zone Granites occurring at north of the eastern end of the region. Because the OARs were inter- 
preted as one large body (Kawasaki, 1980), the age of the OARs had been discussed using data from only one of the bodies (e.g., Shibata and Nozawa, 1968a; Hayase and Ishizaka, 1967). However, later chemical and petrological studies revealed that it consists of several small plutons rather than one large pluton (Kawasaki, 1980; Murata et al., 1983; Murata, 1984). This study contributes the discussion on age difference (or concordance) between the bodies (Itaya et al., 1982; Sumii et al., 1997) of the OARs, and further on contemporaneity of the Outer Zone Granites.

\section{GeOlOgICAL SETTING AND SAMPLING}

The OARs occur in the central mountainous land of the Kii peninsula intruding into the Permian Chichibu Belt, the Cretaceous and Paleogene Shimanto Belt, and the Miocene Kumano Group (Fig. 1). It consists of seven plutons with diameters less than $5 \mathrm{~km}$ across, named Dorogawa, Shirakura, Kose, Tenguyama, Asahi, Shiratani and Katago-Mukuro Dike. The plutons generally consist of granodiorite, granite and granite porphyry (Kawasaki, 1980). Murata et al. (1983) divided the plutons into two types of

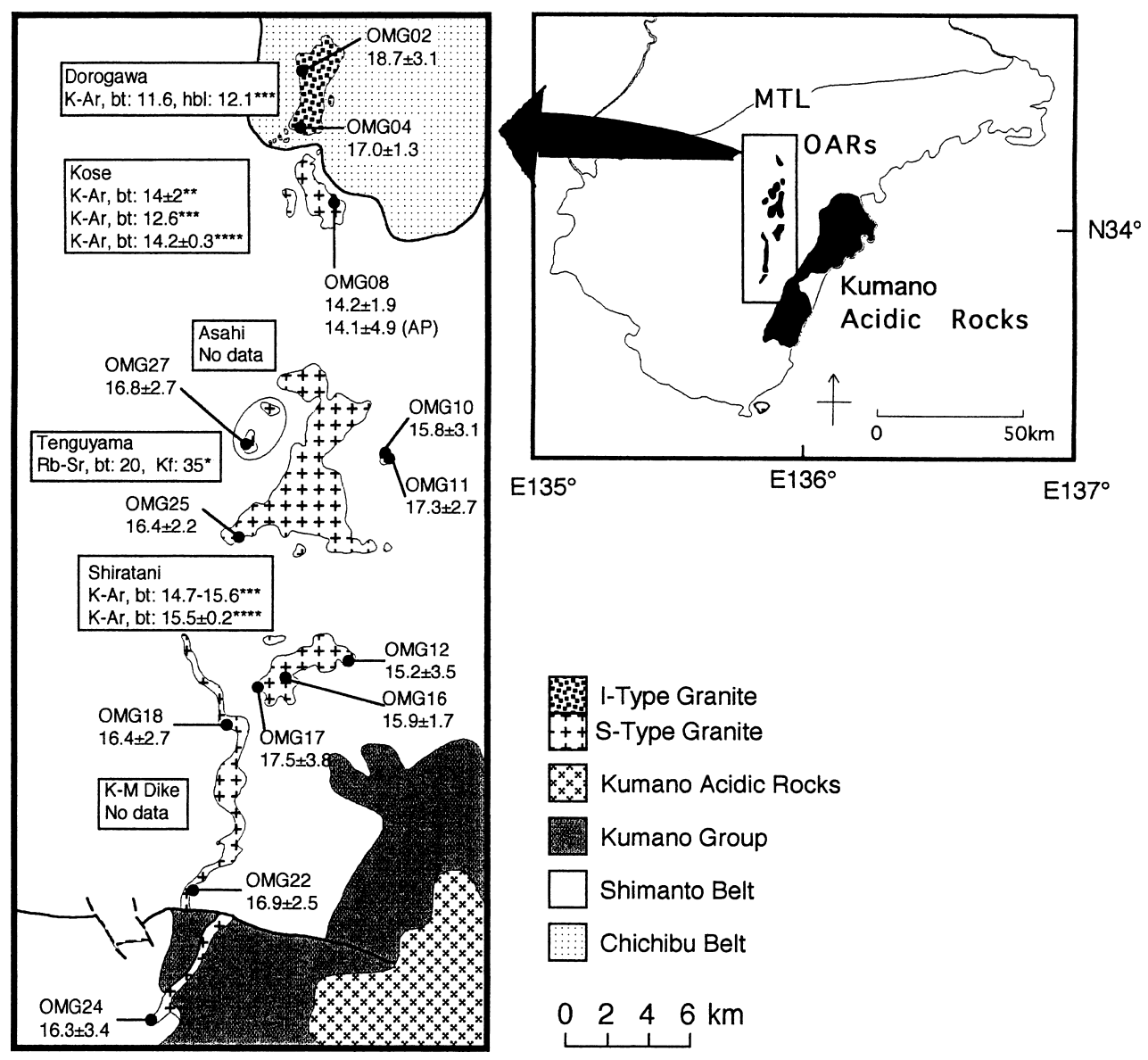

Fig. 1. Sampling localities are shown as solid circles along with obtained ages (Ma, $\pm 2 \sigma)$. All data are FT zircon ages except for one with "AP" which is an apatite age. Previously reported data are also shown in rectangles. *Hayase and Ishizaka, 1967; **Shibata and Nozawa, 1968a; ***Itaya et al., 1982; ****Sumii et al., 1997. Abbreviation for mineral names are as follows: $b t=$ biotite, $h b l=$ hornblende, $K f=K$-feldspar. Map is modified based on Tokuoka et al. (1981), Shiida et al. (1989), Yamada et al. (1990) and Kurimoto et al. (1998). 
I- and S-type granitoid following the definition by Chappel and White (1974). The Dorogawa and Shirakura plutons are I-type granodiorite probably generated from igneous source materials and the others (Kose, Tenguyama, Asahi, Shiratani and Katago-Mukuro Dike) are S-type granite that could be generated in sedimentary source material. A couple of rock samples were collected from each pluton except for the Shirakura pluton that shows small distribution near Dorogawa pluton. Some samples are sandstone hornfels or complex rock of granitic and basement parts. The locations of rock samples are shown in Fig. 1 as solid circles. Rock facies of samples are explained in Table 1 .

\section{Experimental Procedure}

Zircon and apatite crystals were analysed by FT method using the external detector method (e.g., Naeser, 1976) and zeta calibration approach (Hurford and Green, 1983; Hurford, 1990). The experimental procedure used in this work was described by Tagami et al. (1988) in detail. For zircon samples, etching took 20-50 hours in $\mathrm{NaOH}: \mathrm{KOH}$ eutectic etchant. Apatite samples were etched in $0.6 \% \mathrm{HNO}_{3}$ at $32.0 \pm 0.5^{\circ} \mathrm{C}$ for 1.5 minutes. A low-uranium muscovite sheet was used as an external detector to record the induced tracks of minerals and to measure the thermal neutron flux. They were attached to the mounts of

Table 1. Fission track analytical results

\begin{tabular}{|c|c|c|c|c|c|c|c|c|c|c|c|}
\hline Pluton & Code & Rock & $\begin{array}{c}\rho_{\mathrm{s}} \\
\left(10^{6} \mathrm{~cm}^{-2}\right)\end{array}$ & $N_{\mathrm{s}}$ & $\begin{array}{c}\rho_{\mathrm{i}} \\
\left(10^{6} \mathrm{~cm}^{-2}\right)\end{array}$ & $N_{\mathrm{i}}$ & $\begin{array}{c}\rho_{\mathrm{d}} \\
\left(10^{6} \mathrm{~cm}^{-2}\right)\end{array}$ & $N_{\mathrm{d}}$ & $\begin{array}{l}T \pm 2 \sigma \\
(\mathrm{Ma})\end{array}$ & $N$ & $\begin{array}{c}P\left(\chi^{2}\right) \\
(\%)\end{array}$ \\
\hline \multirow[t]{3}{*}{ Dorogawa } & OMG02 & GD & 2.61 & 336 & 2.43 & 313 & 0.0976 & 2268 & $18.8 \pm 3.1$ & 7 & 80 \\
\hline & OMG04 & GD & 3.79 & 2573 & 3.82 & 2598 & 0.0960 & 2231 & $17.0 \pm 1.4$ & 19 & 84 \\
\hline & & & & & \multicolumn{4}{|c|}{ Weighted mean of OMG02 and OMG04 } & $17.4 \pm 1.3$ & & \\
\hline \multirow[t]{3}{*}{ Kose } & OMG08 & G & 2.47 & 506 & 2.75 & 563 & 0.0882 & 2049 & $14.2 \pm 1.9$ & 15 & 7 \\
\hline & OMG08AP & G & 0.34 & 42 & 1.70 & 207 & 0.4512 & 2097 & $14.1 \pm 4.9$ & 6 & 69 \\
\hline & & & & & \multicolumn{4}{|c|}{ Weighted mean of OMG08 and OMG08AP } & $14.2 \pm 1.7$ & & \\
\hline \multirow[t]{3}{*}{ Tenguyama } & OMG10 & GwS & 2.26 & 205 & 2.49 & 226 & 0.0976 & 2268 & $15.9 \pm 3.2$ & 8 & 69 \\
\hline & OMG11 & GwS & 3.05 & 383 & 2.78 & 350 & 0.0882 & 2049 & $17.3 \pm 2.8$ & 6 & 3 \\
\hline & OMG25 & G & 2.90 & 508 & 3.08 & 541 & 0.0976 & 2268 & $16.4 \pm 2.2$ & 13 & 93 \\
\hline \multirow[t]{2}{*}{ Asahi } & OMG27 & G & 3.23 & 357 & 3.04 & 336 & 0.0882 & 2049 & $16.8 \pm 2.7$ & 9 & 26 \\
\hline & & & & & \multicolumn{4}{|c|}{ Weighted mean of OMG25 and OMG27 } & $16.6 \pm 1.7$ & & \\
\hline \multirow[t]{4}{*}{ Shiratani } & OMG 12 & GP & 1.56 & 145 & 1.76 & 164 & 0.0960 & 2231 & $15.2 \pm 3.6$ & 6 & 24 \\
\hline & OMG 16 & G & 2.28 & 883 & 2.25 & 874 & 0.0882 & 2049 & $16.0 \pm 1.8$ & 16 & 6 \\
\hline & OMG17 & SS & 2.84 & 185 & 2.56 & 167 & 0.0882 & 2049 & $17.5 \pm 3.9$ & 5 & 90 \\
\hline & & & & & \multicolumn{4}{|c|}{ Weighted mean of OMG12 and OMG16 } & $15.9 \pm 1.6$ & & \\
\hline \multirow[t]{4}{*}{ K-M Dike } & OMG 18 & SS & 3.77 & 348 & 3.63 & 333 & 0.0882 & 2049 & $16.4 \pm 2.7$ & 7 & 5 \\
\hline & OMG22 & GP & 3.33 & 406 & 3.43 & 419 & 0.0976 & 2268 & $16.9 \pm 2.6$ & 8 & 45 \\
\hline & OMG24 & GP & 2.15 & 195 & 2.26 & 205 & 0.0960 & 2231 & $16.4 \pm 3.4$ & 6 & 31 \\
\hline & & & & & \multicolumn{4}{|c|}{ Weighted mean of OMG22 and OMG24 } & $16.7 \pm 2.1$ & & \\
\hline
\end{tabular}

Note: $\rho_{s}=$ density of spontaneous tracks; $N_{s}=$ number of spontaneous tracks counted to determine $\rho_{s} ; \rho_{i}=$ density of induced tracks in a sample; $N_{i}=$ number of induced tracks counted on a muscovite external detector to determine $\rho_{i} ; \rho_{d}=$ density of induced tracks in NBS-SRM612 dosimeter glass; $N_{d}=$ number of induced tracks counted in muscovite external detector to determine $\rho_{d} ; T=F T$ age calculated from pooled $N_{s}$ and $N_{i}$ for all grains counted; $N=$ number of counted grains; $P\left(\chi^{2}\right)=$ probability of $\chi^{2}$ for $N-1$ degrees of freedom (Galbraith, 1981); K-M Dike means Katago-Mukuro Dike. AP in code represents the data for apatite. Others are for zircon. GD = granodiorite; $G w S=$ complex rock of granitic and besement sandstone parts collected from boundary of an intrusion and basement rocks; G = granite; SS = sandstone hornfels; GP = granite porphyry. 
minerals and dosimeter glass NBS-SRM612, and irradiated in Thermal Column Pneumatic Tube facility of Kyoto University Research Reactor (KUR-1). The induced tracks were revealed by etching the mica sheet in $47 \% \mathrm{HF}$ at $32.0 \pm 0.5^{\circ} \mathrm{C}$ for four minutes. Etched tracks (spontaneous tracks in a mineral and induced tracks recorded on mica detectors for both mineral and dosimeter glass) were counted under a Nikon Biophot transmitted microscope with $100 \times$ dry objective and $10 \times$ eye pieces that result in the true measured magnification of $925 \times$. The $\zeta$ values of $358.9 \pm$ $14.0(2 \sigma)$ for zircon and $309.6 \pm 23.4(2 \sigma)$ for apatite were adopted for age calculation (e.g., Hasebe et al., 1993, 1997).

\section{RESULTS}

FT ages were obtained from 13 sites. The analytical results are shown in Table 1. All of granodiorite, granite and granite porphyry samples passed the $\chi^{2}$-test at the $5 \%$ criterion (Galbraith, 1981; Green, 1981). This result suggests that the age variations between grains in samples are within that allowed for under the conventional Poissonian statistics and that these ages are considered as cooling ages of the plutons. Other samples also passed the $\chi^{2}$-test except for OMG11 from the Tenguyama pluton, showing concordant ages with the age of the nearest plutons. This means that the age of the basement rock samples has been reset by the intrusion of the granite. The OMG11, which did not pass the test $\left(P\left(\chi^{2}\right)=3 \%\right)$, contains a few zircon grains of rounded shape having higher spontaneous track densities. The age may not been reset completely by the intrusive event.

The weighted mean age is calculated to represent a cooling age of each pluton because obtained ages for each pluton are concordant. For Kose pluton, FT ages of zircon and apatite are concordant, suggesting the rapid cooling of the body through the zircon and apatite closure temperatures. Tenguyama and Asahi plutons yield concordant ages. On the basis of chemical and petrographical studies, Kawasaki (1980) inter- preted that the Asahi pluton is a part of the Tenguyama pluton. Obtained ages also support this interpretation. Hence a weighted mean age of samples from the Asahi and Tenguyama is calculated to represent cooling time of the pluton.

Following lines of reasoning, i.e., the relatively small size of these plutons, rapid cooling revealed on the Kose pluton, and existence of age unresetting part in nearby basement rocks even by the largest Tenguyama pluton, lead us to the idea that plutons intruded at shallow level and cooled rapidly. Thus obtained cooling ages should nearly represent the emplacement age for each pluton. These ages are consistent with the data by K-Ar method (Shibata and Nozawa, 1968a; Sumii et al., 1997), giving one more evidence for rapid cooling. Although K-Ar ages by Itaya et al. (1982) were slightly younger than obtained data here, this could be attributed to the unstable condition of the K-Ar laboratory at the very beginning of its history (Itaya, personal communication). The Rb$\mathrm{Sr}$ ages from the Tenguyama pluton (Hayase and Ishizaka, 1967) are significantly older than the FT and K-Ar ages. Although the FT ages are considered here to represent the time of pluton emplacement, the $\mathrm{Rb}-\mathrm{Sr}$ ages do not necessarily express the same time with FT ages because of low mobility of the elements applied for this technique. $\mathrm{The} \mathrm{Rb}-\mathrm{Sr}$ age could offer the oldest limit for the intrusive time. Or, considering that the Kose pluton is the S-type granite, the $\mathrm{Rb}-\mathrm{Sr}$ age could be older than the true age because of possible contamination of radiogenic daughter delivered from original sedimentary material which produce the granitic magma.

\section{The Ages OF THE OARS}

Among five plutons, one pluton (Kose) seems to be slightly younger than others. Whether all plutons belong to the same age population or not is considered statistically using the $\chi^{2}$-test. The possibility that all five plutons belong to one age population, which is represented by the weighted mean age and error of all plutons, is less than $0.1 \%$. On the other hand, the probability of $\chi^{2}$ 
value is $10 \%$ for the assumption that four bodies except for the Kose pluton belong to the one age population, giving no evidence to reject the assumption of the synchronous intrusion of the other four plutons. When one of the other plutons (Dorogawa, Tenguyama, Shiratani, or KatagoMukuro Dike) is excluded from the population, the $\chi^{2}$-test demonstrates that the possibilities of four plutons to belong to one age population are still less than $0.1 \%$. Based on these statistical tests, at least the Kose pluton yields the intrusive age different from the others. It is difficult to state that the intrusive ages for other four plutons are different, and the weighted mean age of four is calculated as $16.8 \pm 0.8(2 \sigma)$ Ma to represent the time of intrusive event. The Kose pluton intruded at $14.2 \pm 1.7(2 \sigma)$ Ma slightly later than others. This result indicates that magma chemistry (I-type and S-type) is not associated with the time of intrusion, which is shown by the concordant age of intrusion between Dorogawa (I-type) and other Stype plutons except for the Kose.

\section{The Ages of The OUter Zone Granites}

The ages of granitic intrusions in the Outer Zone are listed in Table 2. Age varies between 11 to $17 \mathrm{Ma}$. This variation could depend on the quality and meaning of data, because the table includes data which meanings are not discussed by the original authors. The data by recent researches (e.g., researches in 1990's) still show significant scattering in spite that they indicate the age of intrusion after the considerable discussion. The older

Table 2. The radiometric ages of granitic intrusions in the Outer Zone, Southwest Japan. The ages of Omine Acidic Rocks (OAR) are restricted those obtained in this study. For other granites, ages obtained recently are listed in case that there are several studies by the same method. Ages in parenthesis include data obtained from several rock facies. The question marks in the age column denote data with no information about that error represent $\sigma$ or $2 \sigma$. See the sited references for the detailed description of stages of Cape Ashizuri.

\begin{tabular}{|c|c|c|c|}
\hline Pluton & Method & Age $\pm 2 \sigma(\mathrm{Ma})$ & References \\
\hline \multicolumn{4}{|l|}{ Kii Peninsula } \\
\hline OARs but Kose & $\mathrm{FT} ; \mathrm{zr}$ & $16.8 \pm 0.8$ & This work \\
\hline Kose, $O A R$ & $\mathrm{FT} ; \mathrm{zr}$ & $14.2 \pm 1.7$ & This work \\
\hline \multirow[t]{2}{*}{ Kumano Acidic Rocks } & FT; zr, ap & $14.3 \pm 0.5$ & Hasebe et al., 1993 \\
\hline & $\mathrm{K}-\mathrm{Ar} ; \mathrm{bt}$ & $(14.2-14.4) \pm 0.4$ & Sumii et al., 1998 \\
\hline \multicolumn{4}{|l|}{ Shikoku } \\
\hline Omogo & $\mathrm{K}-\mathrm{Ar} ; \mathrm{bt}$ & $14 \pm 2(?)$ & Shibata and Nozawa, $1968 b$ \\
\hline \multirow[t]{2}{*}{ Takatsukiyama } & $\mathrm{FT} ; \mathrm{zr}$ & $14.8 \pm 0.9$ & Tagami and Shimada, 1996 \\
\hline & $\mathrm{K}-\mathrm{Ar} ; \mathrm{bt}$ & $12 \pm 2(?)$ & Shibata and Nozawa, $1968 b$ \\
\hline Kashiwajima & $\mathrm{Rb}-\mathrm{Sr} ; \mathrm{wr}$ & $16 \pm 2$ & Dai et al., 1993 \\
\hline \multicolumn{4}{|l|}{ Cape Ashizuri } \\
\hline \multirow[t]{2}{*}{ stage II } & $\mathrm{FT} ; \mathrm{zr}$ & $16.1 \pm 0.7$ & Murakami et al., 1989 \\
\hline & $\mathrm{K}-\mathrm{Ar} ; \mathrm{bt}$ & $12.9 \pm 0.6(?)$ & Murakami et al., 1989 \\
\hline stage IV & $\mathrm{FT} ; \mathrm{zr}$ & $11.3 \pm 0.4$ & Murakami et al., 1989 \\
\hline stage IV? & $\mathrm{K}-\mathrm{Ar} ; \mathrm{bt}$ & $13 \pm 2(?)$ & Shibata and Nozawa, $1968 b$ \\
\hline \multicolumn{4}{|l|}{ Kyushu } \\
\hline \multirow{2}{*}{ Osuzuyama } & FT; zr & $14.9 \pm 1.4$ & Iwaya and Mimura, 1992 \\
\hline & $\mathrm{K}-\mathrm{Ar} ; \mathrm{bt}$, wr & $(15.1-16.6) \pm 1.6$ & Iwaya and Mimura, 1992 \\
\hline & $\mathrm{K}-\mathrm{Ar} ; \mathrm{bt}$ & $13.8 \pm 0.9(?)$ & Shibata, 1978 \\
\hline \multirow[t]{2}{*}{ Minami Osumi } & $\mathrm{K}-\mathrm{Ar} ; \mathrm{bt}$ & $14.4 \pm 0.7(?)$ & Shibata, 1978 \\
\hline & $\mathrm{FT} ; \mathrm{zr}$ & $(13.9-15.3) \pm(1.3-1.5)$ & Miyachi, 1990 \\
\hline
\end{tabular}

Note: FT: fission track method, zr: zircon, ap: apatite, $K$-Ar: K-Ar method, bt: biotite, wr: whole rock. 
age of the OARs appears to be excluded from the contemporaneous timing of granitic activities in the Outer Zone, indicating the existence of igneous activity prior to the contemporaneous granitic intrusion. Granitic activities could occur twice or repeatedly in the Outer Zone. Ages of the intrusions could have some relationships with their locations. The future geochronological studies on other Outer Zone Granite would give a guide to understand the significance of age difference found in this study.

\section{CONCLUSIVE REMARKS}

(1) FT age determination, along with the $\chi^{2}$ statistical test, reveals that the OARs have two intrusive times; one is $16.8 \pm 0.8 \mathrm{Ma}$ for Dorogawa, Tenguyama, Shiratani and KatagoMukuro Dike, and the other is 14.2 \pm 1.7 Ma for Kose pluton.

(2) The difference in magma chemistry of Iand S-type in the OARs does not correspond to the deference in the time of intrusion, which was demonstrated by concordant ages between Dorogawa (I-type) and Tenguyama, Shiratani and Katago-Mukuro Dike (S-type).

(3) The correlation of intrusive ages between the OARs and the other Outer Zone Granites indicates that the parts of OARs intruded earlier than the others.

Acknowledgments-We wish to express our appreciation to Takahiro Tagami and Masayuki Torii for giving us helpful advises and discussion. We are also greatly gratitude to Tetsumaru Itaya and Tomoaki Sumii who helped us interpret $\mathrm{K}$-Ar ages on the region. Takaaki Matsuda and Sataro Nishikawa are also acknowledged for their help with irradiation process using TC-Pn facility at Research Reactor Institute, Kyoto University. Ken Shibata and anonymous reviewer are thanked by their comments on the manuscript. The rock sampling would become difficult without the help of Tetsu Yoshioka and Ryuji Yamada. Part of this work is supported by a Science Technology and Industrial Development Program (STAID), under Overseas Education Cooperative Fund Loan Agreement, coordinated by the State Ministry for Research and Technology of the Republic of Indonesia (April 1992-March 1995).

\section{REFERENCES}

Chamot-Rooke, N., Renard, V. and LePichon, X. (1987) Magmatic anomalies in the Shikoku Basin: A new interpretation. Earth Plant. Sci. Lett. 83, 214-228.

Chappel, B. W. and White, A. J. R. (1974) Two contrasting granite types. Pacific Geol. 8, 173-174.

Dai, K., Tsusue, A. and Honma, H. (1993) Petrological study of granitic rocks from the KashiwajimaOkinoshima district in the southwestern part of Kochi Prefecture. J. Min. Petr. Econ. Geol. 88, 247-264.

Galbraith, R. F. (1981) On statistical models for fission track counts. Math. Geol. 13, 471-488.

Green, P. F. (1981) A new look at statistics in fissiontrack dating. Nucl. Tracks 5, 77-86.

Hasebe, N., Tagami, T. and Nishimura, S. (1993) The evidence of along-arc differential uplift of the Shimanto accretionary complex: Fission track thermochronology of the Kumano Acidic Rocks, Southwest Japan. Tectonophysics 224, 327-335.

Hasebe, N., Tagami, T. and Nishimura, S. (1997) Melange forming processes in the development of an accretionary prism: Evidence from fission track thermochronology. J. Geophys. Res. 102, 7659-7672.

Hayase, I. and Ishizaka, K. (1967) Geological age by Rb-Sr method. J. Jpn. Petrol. Min. Econ. Geol. 58, 201-212.

Hurford, A. J. (1990) Standardization of fission track dating calibration: recommendation by the fission track working group of the I.U.G.S. subcommission on geochronology. Chem. Geol. Isot. Geosci. Sect. 80, 171-178.

Hurford, A. J. and Green, P. F. (1983) The zeta age calibration of fission-track dating. Isotope Geosci. 1, 285-317.

Itaya, T., Nagao, K., Murata, M. and Ogata, K. (1982) Rare gas composition and K-Ar ages of I and S-types in the Omine granitic rocks, central Kii Peninsula, Japan. Abstract in Fifth International Conference on Geochronology, Cosmochronology and Isotope Geology, 164-165.

Iwaya, T. and Mimura, K. (1992) K-Ar and fission-track ages of the Osuzuyama volcano-plutonic complex in Miyazaki Prefecture, Southwest Japan. Bull. Geol. Surv. Jpn. 43, 565-572.

Kawasaki, M. (1980) Omine Acid Rocks, Kii Peninsula: Geology and major element chemistry. J. Jpn. Assoc. Min. Petr. Econ. Geol. 75, 86-102.

Kurimoto, C., Mikimoto, H., Yoshida, F., Takahashi, Y. and Kamazawa, M. (1998) Geological map of Japan 1/200,000 Wakayama, Geol. Surv. Japan.

Miyachi, M. (1990) Zircon fission-track ages of the Tertiary granitic rocks in the Satsuma peninsula, southern Kyushu, Japan. J. Geol. Soc. Jpn. 96, 155157. 
Murakami, N., Imaoka, T. and Uozumi, S. (1989) Ring complex of the Cape of Ashizuri, and its mode of emplacement, Kohchi Prefecture, Southwest Japan. The Collapse Basins-Its Structures, Formation Mechanisms and Practical Significance-, Ass. Geol. Coll. Jpn. Monograph 36, 115-142.

Murata, M. (1984) Petrology of Miocene I-type and Stype granitic rocks in the Ohmine district, central Kii peninsula. J. Jpn. Assoc. Min. Petr. Econ. Geol. 79, 351-369.

Murata, M., Itaya, T. and Ueda, Y. (1983) Sulphide and oxide minerals from the Ohmine Granitic Rocks in Kii Peninsula, Central Japan and their primary paragenetic relations. Contrib. Mineral Petrol. 84, $58-65$.

Naeser, C. W. (1976) Fission Track Dating. US Geol. Surv., Open File Rep., 58 pp.

Otofuji, Y., Hayashida, A. and Torii, M. (1985) When was the Japan Sea opened?: palaeomagnetic evidence from Southwest Japan. Formation of Active Ocean Margins (Nasu, N., Kobayashi, K., Veda, S., Kushiro, I. and Kagami, H., eds.), 551-566, Terrapub, Tokyo.

Shibata, K. (1978) Contemporaneity of Tertiary granites in the Outer Zone of Southwest Japan. Bull. Geol. Surv. Jpn. 29, 551-554.

Shibata, K. and Nozawa, T. (1967) K-Ar ages of granitic rocks from Outer Zone of Southwest Japan. Geochem. J. 1, 131-137.

Shibata, K. and Nozawa, T. (1968a) K-Ar ages of Ominesan Acid Rocks, Kishu, Japan. Bull. Geol. Soc.
Jpn. 19, 7-10.

Shibata, K. and Nozawa, T. (1968b) K-Ar Ages of Granitic Rocks of Ashizuri-misaki, Takatsukiyama and Omogo, Shikoku, Japan. Bull. Geol. Surv. Jpn. 19, 11-16.

Shiida, I., Suwa, K., Umeda, K. and Hoshino, M. (1989) Geology "Sanjo-ga-Take" district, 1/50,000, Geol. Surv. Japan.

Sumii, T., Uchiumi, S., Shinjoe, H. and Shimoda, G. (1997) Re-examination of the K-Ar age of Kumano Acidic Rocks and Omine Acidic Rocks. Abstract of Ann. Meeting Geol. Soc. Japan, p. 396.

Sumii, T., Uchiumi, S., Shinjoe, H. and Shimoda, G. (1998) Re-examination on K-Ar age of the Kumano Acidic Rocks in Kii Peninsula, Southwest Japan. J. Geol. Soc. Jpn. 104, 387-394.

Tagami, T. and Shimada, C. (1996) Natural long-term annealing of the zircon fission-track system around a granitic pluton. J. Geophy. Res. 101, 8245-8255.

Tagami, T., Lal, N., Sorkhabi, R. B., Ito, H. and Nishimura, S. (1988) Fission track dating using external detector method: A laboratory procedure. Mem. Fac. Sci., Kyoto Univ., Series of Geol. Min. 53, 130.

Tokuoka, T., Harata, T., Suzuki, H. and Yao, A. (1981) Geological Sheet Map 1:200,000 "Tanabe”, Geol. Surv. Japan.

Yamada, N., Saito, E. and Murata, Y. (eds.) (1990) Computer-generated Geologic Map of Japan. 1:2,000,000 Map series, No. 22, Geol. Surv. Japan. 